\title{
Migration Networks in the OECD Countries
}

\author{
Wadim Strielkowski \\ Assistant Professor, Department of Marketing Communication and PR, Faculty of Social Sciences, \\ Charles University in Prague, Smetanovo nabr. 6, 11001 Praha 1, Prague, Czech Republic \\ Email: strielkowski@fsv.cuni.cz \\ Emily Welkins \\ Independent Scholar \\ Email: emily@emilywelkins.com
}

\section{Doi:10.5901/mjss.2015.v6n2p501}

\section{Abstract}

Our paper focuses on the formation and existence of migration networks in the OECD countries. Immigrant networks, or spatial concentration of immigrants from the same region, can be observed in many countries that are net receiver of migration flows. We construct an econometric model for checking for dependency between the number of recent immigrants and the stocks of foreign population at a given country; this is tested against the alternative hypothesis of the dominating influence of economic factors on migration. Using the data from selected OECD countries we find an empirical verification of immigrants' networking both for the whole volume of foreign immigrants' inflow and by selected nationalities. Our conclusions show that migration networks exist and are abundant in migration communities in various countries worldwide.

Keywords: international migration, networks, econometric model, OECD countries

\section{Introduction}

Human beings live in communities and form even small groups within large communities. To put it into stricter terms they have a tendency to "network". Also important is the context specificity of the situation in which we are talking about the groups (see Memar et al., 2013). Also it may be noted that that there is a "common interest" that binds them together into a "network". Like everyone else, immigrants that have left their home country and are looking for a chance to increase their well-being elsewhere, tend to create networks. The context specificity of the situation is loosing the safe and wellknown grounds of the home country, with a multitude of interpersonal social ties.

Immigrants' networks formation has long been of a specific interest among economists and social scientists (Nae, 2013; or Farooq et al., 2014). Networking or geographical concentration of migrants from the same source region who are distinguished by the same ethnic origin, background or language is frequently observed in many countries. For instance, there is a large immigrants' community of Tamils in Switzerland, Turks in Germany, Italians in Argentina, Albanians and Bosnians in Italy, Ukrainians in the Czech Republic, Romanians in Italy, or Mexicans in the U.S. While in some cases the formation of immigrants' networks is influenced by the geographic proximity of the host and target countries (i.e. Mexico and U.S. or Albania and Italy), in other cases it might be the language proximity (i.e. Romania and Italy), while there are also cases when one has a reason to believe that there are some other determinants of the process of migrants' networking (see e.g. Nae, 2013).

It seems that in a large number of cases not only ethnic and language similarities do matter but also spatial characteristics create basis for such networks' formation: for instance, there are Macedonians from Skopje who constitute large immigrants' community in Gothenburg, Sweden or people from the town of Siemiatycze in the north-east of Poland who form a large emigrants' group in Brussels, Belgium. The story of these networks is quite simple: a person from a small town or a rural community moves to the foreign country. After a considerable period of time necessary for settling down this person is followed by the closest family and relatives. Those people are then followed by their closest relatives, friends and neighbors and so on. In such a case local knowledge and "knowing-your-neighbor" which is mostly developed in dense communities where people know each other well appear to be of greater importance than the ethnic or cultural ties. 
This paper contributes to the existing migration literature and migrants' network formation phenomenon in a number of ways: first, it attempts to verify the hypothesis of network formation using empirical analysis of the available data from selected OECD countries. We are trying to test the hypothesis of international immigrants' networks formation based on the ethnic (geographical) origin versus the hypothesis of migration networks formed on the basis of economic incentives in the target country (county of immigration).

\section{Migrants' Network-Formation Behavior}

Generally, in the existing migration literature there are two basic approaches to be distinguished that concern the theory of formation of migration networks: i) network externalities and ii) so-called "herd behavior" (see for example Bauer et al., 2002; or Winters et al., 2001).

Beneficial network externalities appear when a network of established immigrants reduces the costs of relocation to a foreign culture by providing assistance in finding a job as well as food and shelter to the recent immigrants. Thus, by joining the ethnic community the immigrant increases his positive utility (see for example Gottlieb, 1987; Grossman, 1989; Stark, 1991; and Church and King, 1993). On the contrary, negative network externalities arise when high productivity immigrants do not want low-productive immigrants (Stark, 1991; Stark, 1995) or if growing number of foreigners in a specific location increases competition for jobs and lowers wages. In this case immigrant will not be able to profit from the presence of his compatriots in the given location.

Herd behavior encourages migrants to discount private information. According to this hypothesis an emigrant will follow the flow of other immigrants assuming that they have the information that is not obvious to him (Bauer et al., 2002).

\section{Econometric Model: Is there any Evidence for Immigrant's Networks Formation?}

In thus subsection of our paper we are drawing an econometric model of testing for the immigrants' network-formation. Our objective is to show the network-formation behavior empirically using the evidence from the real life.

We are testing a hypothesis of international migration that results in network formation against an alternative hypothesis of migration induced by the economic incentives (differences in GDP, higher wage premium, etc.) and leading to no networks. The on-going debate in migration literature is the one trying to link international migration to economic factors. Here, wage differentials between the poorer country (country of emigration) and somewhat wealthier country (country of immigration), differences in GDP per capita or differences in unemployment are claimed to provide the basis for migration, or, be its decisive factors.

We do not want to underestimate the influence of these factors, however we are concerned with the fact that quite often economic incentives give way to so-called "social factors" that most of the migration literature tries to omit. The socalled "social factors" include influence of the family, friends, and language barrier and, of course, positive or negative externalities provided by the immigrants' networks. No doubt that international migration would have never happened without economic "pull-factors", however we assume that there is a strong influence of immigrants' networks that should be taken into account. Using the econometric regression analysis we are attempting to: a) see if there is any empirical evidence of network-formation behavior, and b) test to what extent networks can be approximated for the migration decisive pull-factor.

Following Zavodny (1998) we set up a simple regression model in order to investigate the determinants of where the new immigrants coming to the OECD selected countries settle. The number of immigrants is regressed on variables that measure the demographic characteristics and economic conditions, or:

$$
\mathrm{I}_{\mathrm{kt}}=\alpha+\beta \operatorname{Demog}_{k t}+\delta E c o n_{k t}+\varepsilon_{k t} \text {, (1) }
$$

where $I_{k t}$ is the log number of persons immigrating to state $k$ in time $t$. Equation (1) is estimated using the annual data on new immigrants settling down in selected OECD countries in 1992-2001, or 110 observations.

The vector Demog $_{k t}$ includes logs of total population by each country that is foreign-born, the vector $E c o n_{k t}$ includes logs of GDP per capita, employment rates and compensation per employee by each of the corresponding country.

To start our analysis with, we will run the test of interdependence for the whole volume of inflow of foreign immigrants in all OECD countries and various economic and demographic factors. Equation (1) takes the following form:

$$
\mathrm{I}_{\mathrm{kt}}=\alpha+\beta_{1} \text { FOREIGN }+\beta_{2} \text { POPUL }_{k t}+\beta_{3} U N E M P L \beta_{3 k t}+\beta_{4} Y_{P P}+\varepsilon_{k t} \text {, (2) }
$$

where $\mathrm{I}_{\mathrm{kt}}$ is the log number of persons immigrating to state $k$ in time $t$. FOREIGN is the log of number of foreign 
immigrants by country in 1992-2001, POPUL is log of the total population per respective countries and UNEMPL is the log of unemployment rate and $Y_{P P}$ is the log of GDP per capita per respective countries.

The regression model has been tested using STATA software package. Table 1 reports the main findings.

It appears that with relatively high R-squared, low p-values and high coefficients of determination the presence of foreigners in a country can be a decisive factor on attracting other foreign immigrants. It seems that we have a high probability of actual formation of immigrants' networks taking place in OECD countries.

Table 1: Determinants of migrants' flows and networks in OECD countries (1992-2001)

\begin{tabular}{|l|c|c|c|c|c|c|}
\hline FOREIGN_INFLOW & coefficient & std. error & $\mathbf{t}$ & $\mathbf{P}>|\mathbf{t}|$ & [95\% conf. interval] \\
\hline FOREING_POPUL & .7185448 & .0442711 & 16.23 & 0.000 & .6307633 & .8063263 \\
\hline POPUL & .3812127 & .0428267 & 8.90 & 0.000 & .2962953 & .46613 \\
\hline UNEMPL & -.018744 & .0782169 & -0.24 & 0.811 & -.1738336 & .1363456 \\
\hline GDP_PP & 1.171447 & .1835216 & 6.38 & 0.000 & .8075572 & 1.535336 \\
\hline Cons & -6.910304 & .8718255 & -7.93 & 0.000 & -8.638973 & -5.181635 \\
\hline R-squared & \multicolumn{7}{|c|}{0.94} \\
\hline Adj. R-squared & \multicolumn{7}{|c|}{0.94} \\
\hline N = & \multicolumn{7}{|c|}{110} \\
\hline
\end{tabular}

Source: own estimations

Now, let us refine the model and run the analysis using the data from OECD countries, but this time with a special impact on selected ethnic groups. This will give us the possibility to follow whether people originating at the same country really form networks due to the effects mentioned previously. We shall introduce a simple regression model which will be a modification of (2):

$$
\mathrm{I}_{\mathrm{Nkt}}=\alpha+\beta_{1} N_{\mathrm{TRt}}+\beta_{2} P O P U L_{k t}+\beta_{3} U N E M P L \beta_{3 k t}+\beta_{4} Y_{P P}+\beta_{5} F D R+\varepsilon_{k t},
$$

where ${ }^{\mathrm{I}_{\mathrm{Nkt}}}$ is the log number of immigrants of a particular ethnical origin $N$ immigrating to country $k$ at time $t$, $U N E M P L$ is the log of the unemployment rate in country $k, Y_{P P}$ is the log of GDP per capita in country $k$ and $F D R$ is the ratio of foreign-born population of a country $\mathrm{k}$ to its domestic population.

Table 2: Determinants of migrants' flows and networks in OECD countries: the case of Turkish immigrants (1996-2002)

\begin{tabular}{|l|c|c|c|c|c|c|}
\hline TR_INFLOW & Coefficient & std. error & $\mathbf{t}$ & $\mathbf{P}>|\mathbf{t}|$ & \multicolumn{2}{|c|}{ [95\% conf. interval] } \\
\hline TR_STOCK & .4599809 & .1124223 & 4.09 & 0.001 & .2237905 & .6961714 \\
\hline GDP_PP & -.523562 & .5426682 & -0.96 & 0.347 & -1.663666 & .6165416 \\
\hline POPUL & .7895055 & .2063266 & 3.83 & 0.001 & .3560293 & 1.222982 \\
\hline UNEMPL & -.3206025 & .2478602 & -1.29 & 0.212 & -.8413374 & .2001325 \\
\hline FOREIGN/DOM_RATE & -.1274654 & .1927268 & -0.66 & 0.517 & -.5323694 & .2774386 \\
\hline CONST & -.8720297 & 2.47726 & -0.35 & 0.729 & -6.07656 & 4.3325 \\
\hline R-squared & \multicolumn{7}{|c|}{0.97} \\
\hline Adj. R-squared & \multicolumn{7}{|c|}{96} \\
\hline N = & \multicolumn{7}{|c|}{96} \\
\hline
\end{tabular}

Now, let us run the model using the data for immigrants of the Turkish origin in OECD countries in 1996-2002 (see Table 2). In addition, let us do the same analysis using the data on immigrants from the U.K. throughout the same time-period (see Table 3). Surely, there is a huge difference between Turkish and British migrants (with the Brits being mostly "holiday" migrants - e.g. people who tend to move to Spain and Portugal, as well as to other "holidays" destinations after their retirement in the United Kingdom). 
Table 3: Determinants of migrants' flows and networks in OECD countries: the case of British migrants (1996-2002)

\begin{tabular}{|l|c|c|c|c|c|c|}
\hline UK_INFLOW & Coefficient & std. error & $\mathbf{t}$ & \multicolumn{2}{|c|}{$\mathbf{P}>|\mathbf{t}|$} & \multicolumn{2}{|c|}{$[95 \%$ conf. interval] } \\
\hline UK_STOCK & .5343193 & .2477629 & 2.16 & 0.045 & .0137888 & 1.05485 \\
\hline GDP_PP & .3982737 & .757652 & 0.53 & 0.606 & -1.193494 & 1.990042 \\
\hline POPUL & .8830804 & .255699 & 3.45 & 0.003 & .3458767 & 1.420284 \\
\hline UNEMPL & -.3926933 & .3790124 & -1.04 & 0.314 & -1.188969 & .4035821 \\
\hline FOREIGN/DOM_RATE & -.2611677 & .224988 & -1.16 & 0.261 & -.7338499 & .2115145 \\
\hline CONST & -5.043333 & 3.579964 & -1.41 & 0.176 & -12.56456 & 2.477891 \\
\hline R-squared & \multicolumn{7}{|c|}{0.9197} \\
\hline Adj. R-squared & \multicolumn{7}{|c|}{0.8974} \\
\hline N = & \multicolumn{7}{|c|}{96} \\
\hline
\end{tabular}

Source: own estimations

Our results for the Turkish and British migrants are similar to the results obtained and reported in Table 1. In both cases, the estimations yielded relatively high R-squared, low p-values and high coefficients of determination. The results seem to be in accord with previous findings for the sample of OECD countries.

\section{Conclusions and Discussions}

European Commission proclaimed that the $21^{\text {st }}$ century will be the "Age of Migrations". Quite true, nowadays we are facing various sorts and kinds of migration: as the world gradually turns into the global village, more and more people are on the move. On of the most important features of migration is immigrants' networking: without support the established immigrants provide for their new compatriots the volume of worldwide migration would be substantially smaller.

In spite of all controversies surrounding the formation of immigrants' networks in the country of immigration, it seems that there is enough evidence to prove that the process of networking does exist. Both empirical analysis and the dynamic networks computer-generated model we have used in our paper show (although from a different perspective and using different tools) that social ties play an important role in forming migration decisions and in facilitating the mechanisms of migration. People tend to form networks that incorporate family, relatives, friends, colleagues and acquaintances: networks are crucial in survival at a given country or given society (after all human beings are social animals) and when such a network is broken by emigration it is likely that the ties persist and in one way or another will influence the individuals remaining in the network.

The mechanism of immigrants' networks formation acts as the following: once in a country of immigration, immigrants start to act as a "pulling force" - they attract the members of their former network and are likely to pull them out of the existing network and make them to migrate. This is how immigrants' networks are formed: it seems that in spite of economic incentives there are those "unpredictable" effects that are often referred to in economic literature that play crucial role in migration. Although difficult to measure, those effects can be represented in a form of a dynamic network model which allows us to see the actual forces behind the processes of networking and emigration. We have used different level of network's "density" in order to prove that with the increasing number of average connections migration is likely to subdue. Moreover, our model shows that when a network is "tense" enough (i.e. it consists of ten and more agents that are all mutually connected), agents lose interest in migration as such. Migration is often seen as a tool to increases individuals' well-being, knowing from tens of thousands to millions of people provides opportunities so wide that no migration is necessary. This might explain why people with a high density of contacts and vivid social life tend to go big in their own countries or societies. Such individuals do not consider migration to be of any help: they would have lost more in spite of positive externalities provided by the immigrants' networks.

\section{References}

Bartel, A. P. (1989). Where Do the New United States Immigrants Live? Journal of Labour Economics, 7 (October), 371-91

Bauer T., Epstein, G. S. and Gang, I. (2002). Herd Effects or Migration Networks? The location Choice of Mexican Immigrants in the US. CEPR Discussion Paper Series, n. 3505

Borjas G. J. (1995). Ethnicity, Neighborhoods, and Human-Capital Externalities. American Economic Review, 85 (3), 365-390

Church, J. and King, I. (1993). Bilingualism and network externalities, Canadian Journal of Economics, 26(2), $337-345$

Farooq, M., Tariq, S., Ghulzar, F., Mirza, F. I., \& Riaz, F. (2014). Determinants of International Migration in Pakistan. Mediterranean Journal of Social Sciences, 5(20), 2028-2032 
Gottlieb, P. (1987). Making Their Own Way: Shorthorn Blacks' Migration to Pittsburgh, 1916-30. Urbana: University of Illinois Press. Grossman, J.R. (1989). Land and Hope: Chicago, Black Southerners, and the Great Migration. Chicago: University of Chicago Press

Harris, J.R. and M.P. Todaro (1970). Migration, Unemployment and Development: A Two Sector Analysis. American Economic Review 60(1), 120-142

Memar, S., Adlipour, S., \& Khosravi, E. (2013). Sociological Analysis of the Relation Between the Uses of Virtual Social Networks and Life Style of the Young (Case Study of Facebook and the Young of Isfahan). Mediterranean Journal of Social Sciences, 4(6), 469-480

Moody, J. (1998). Matrix methods for calculating the triad census. Social Networks, 20, 291-299

Nae, T. R. (2013). Migration and its Effects on Economic and Demographic Development in Romania. Mediterranean Journal of Social Sciences, 4(2), 35-43

OECD Statistical Compendium (2006). Retrieved from: www.oecd.org

Stark, O. (1991). The Migration of Labour. Oxford: Basil Blackwell.

Stark, O. (1995). Altruism and Beyond: An economic analysis of transfers and exchange within families and groups. Cambridge: Cambridge University Press

Todaro, M. P. (1969). A Model of Labor Migration and Urban Unemployment in Less Developed Countries. American Economic Review 59 (1), 138-148

Walsh, B.M. (1974). Expectations, Information, and Human Migration: Specifying an Econometric Model of Irish Migration to Britain. Journal of Regional Science, 14, 107-120.

Walsh, B.M. (1987). The Impact of Demographic Variables on Unemployment, In: The Challenge of Unemployment. Administration, XXXV (3), Dublin

Walsh, B.M. (1987). Why is Unemployment so high in Ireland? In: Perspectives if Economic policy. Centre for Economic research, UCD, Dublin

Walsh, B.M. (1989). Testing for the Existence of Macro Economic Feedback from Large-scale Migration. The Economic and Social Review, Dublin

Wasserman, S., Faust, K. (1994). Social Network Analysis. Cambridge University Press

Winters, P., de Janvry, A. and Sadoulet, E. (2001). Family and Community Networks in Mexico-U.S. Migration. Journal of Human Resources, 36, 159-184

Zavodny, M. (1998). Determinants of Recent Immigrants' Locational Choices. Federal Reserve Bank of Atlanta, Working paper no. 98-3 